\title{
Imperial ambivalences. Histories of lady travellers and the French explorer Octavie Renard-Coudreau (1867-1938)
}

Federico Ferretti

federico.ferretti@ucd.ie

Abstract: This article addresses the life and works of a virtually unknown lady explorer, Octavie Renard-Coudreau (1867-1938), who continued an Amazonian exploration 'alone' after the death of her husband, the maverick French geographer Henri Coudreau (1859-1899). It extends and connects two main bodies of scholarship, the first on women travellers and feminist historical geographies, the second on scientific couples and collaborative partnerships in the history of sciences. I argue that, in addition to textual analysis, the social, biographical, cultural and political contexts of these travels allow a better understanding of the ambivalences that characterised Western travellers and scholars, both men and women, in imperial contexts. This helps avoiding essentialism and recovering the experiences of marginalised figures in the history of geography. The story of Octavie Coudreau has elements of originality that can stimulate new reflections on these points, also because her travel experience was not in the hegemonic Anglophone context, and she was acquainted with unorthodox and dissident geographers of that time. This article also contributes to studies on the influence which anarchist geographers such as Elisée Reclus, a supporter of the Coudreaus, exerted on explorers, though Octavie seemed to keep her distance from this former socialist inspiration.

Keywords: Octavie Coudreau, Lady Travellers, Geography and Empire; Amazonia; Exploration

2017, "Imperial ambivalences. Histories of lady travellers and the French explorer Octavie Renard-Coudreau (1867-1938)", Geografiska Annaler Series B, 99(3), 2017, pp. 238-255 http://www.tandfonline.com/doi/full/10.1080/04353684.2017.1353887 
This article addresses the works of a figure still unknown to scholarship, the 'lady explorer' Octavie Renard-Coudreau (1867-1938), wife of the maverick explorer Henri Coudreau (18591899) (Benoit 2000; Ferretti 2015; Mouchet 1973), who accompanied her husband on his explorations through the tributaries of the Amazon River and then continued these explorations after his death, taking control of their crew from 1899 to 1906 and publishing 6 books to recount these experiences to French-speaking publics. This article contributes to the debates on feminist historical geographies over the last two decades and the histories of lady travellers, drawing upon the concept of 'ambivalence' highlighted by Alison Blunt (1994a, 23-26) and on the idea of 'complex locations' exposed by Avril Maddrell (2009) to respond to the calls to rescue the histories of women in the geographical traditions (Domosh 1991; Domosh and Morin 2003; Monk, Fortuijn and Raleigh 2004; Morin and Berg 1999; Rose and Ogborn 1988) and to empirically address places and actors of geography, exploration and empire (Burnett 2000; Driver 2001; Sidaway, Jacobs and Woon 2014).

I would argue that the case of Octavie Renard provides an extremely original way to understand ambivalences and complex locations of female travellers and geographers during imperial periods for a number of reasons. First, Octavie and her husband faced marginalisation within French colonial institutions; from 1895, the Coudreaus funded both their expeditions and their livelihood on travel grants they negotiated in each instance with the governors of the Brazilian states of Pará and Amazonia. Second, from 1899 to 1906, Octavie took the initiative of continuing these endeavours while remaining completely 'alone' in the sense that she was the only woman, the only white person and the only chief, making her responsible for her expeditions, which took place outside every European institutional context, thus pushing her independence to the highest degree. This recalls the case of Mary Kingsley, analysed by Alison Blunt (1994a and 1994b), though O. Coudreau worked outside her nation's colonial empire and without the same public support and popularity than Kingsley.

2017, "Imperial ambivalences. Histories of lady travellers and the French explorer Octavie Renard-Coudreau (1867-1938)", Geografiska Annaler Series B, 99(3), 2017, pp. 238-255 http://www.tandfonline.com/doi/full/10.1080/04353684.2017.1353887 
Then, her background was not that of mainstream colonial geography, but of the socialists and unorthodox thinkers with whom Octavie and Henri were acquainted in France, especially Elisée Reclus (1830-1905). After the couple's appointment in Brazil (considered a betrayal in French colonial milieus because Brazil was then a rival of the French Empire around the Guianas), the anarchist geographer apparently remained the only scholar to support their publications in Europe. Reclus and the anarchist geographers were interested in these travels because Henri Coudreau furnished one of the first sympathetic accounts of the Amazonian Indians during the years he spent living with indigenous communities after his desertion from the first official mission the French government entrusted to him (Mouchet 1973; Ferretti 2017). Nevertheless, Octavie, who knew Henri after these experiences in Indian tribes, had more conservative political ideas than her husband and seemed to be decidedly less advanced than Reclus in terms of antiracism and anti-colonialism (Ferretti 2013 and 2016a). However, her experience provides an original standpoint for appreciating the works of a woman in extra-European terrain and their complex and contradictory relations to imperial issues.

My main argument is that this case demonstrates the ways in which situated and contextual considerations of individual trajectories are paramount for avoiding essentialism. I simultaneously address the knowledge these individuals produced in its place and in their travels (Livingstone 2003; Naylor 2005) without surrendering gendered lenses and feminist issues in the analysis. Thus, if Sarah Mills rightly noted that when engaging with travel and geography, 'gender always makes a difference' (Mills 1994, 30), I would argue that it is never the only determinant. As Maddrell argued about the experiences of women travellers, 'generalisations may be drawn from their individual experiences, but not universalisations' (Maddrell 2009, 4). Thus, it is increasingly important to lend theory and discourse a materiality (Blunt and McEwan 2002, 5-6) considering that biography, including that of 'smaller lives and less figures' (Guelke and Morin 2001, 323), contributes to putting 'geography firmly in its place' (Baigent 2004, 545) and allows the consideration of all the complexity of European (male and female) scientists' relations with extra-European peoples. Therefore, textual analysis should be integrated with the

2017, "Imperial ambivalences. Histories of lady travellers and the French explorer Octavie Renard-Coudreau (1867-1938)", Geografiska Annaler Series B, 99(3), 2017, pp. 238-255 http://www.tandfonline.com/doi/full/10.1080/04353684.2017.1353887 
study of empirical cases and their materialities, to understand imperial ambivalences as I explain below.

The experience of the Coudreaus can be also considered as a relevant case for the historiography on scientific couples, addressed by a rich literature inspired by the pioneering works of Margaret Rossiter on the so-called Matilda Effect (Rossiter 1993). According to Rossiter, there is a traditional bias in acknowledging the works of female scientists, whose figures are often hidden by the names of male colleagues. Later scholarship has focused on what Helena Pycior, Nancy Slack and Pnina Abir-Am defined creative couples, stressing the importance of collaboration for both partners, though the recognition of female work was often late. According to these authors, in most of the cases of collaboration which have been studied, 'creative work by women has been underestimated. The gender hierarchy of a patriarchal society cannot, however, so easily ignore women who have been coauthors with men or whose contributions have outlasted those of their male partners' (Pycior, Slack and Abir-Am 1996, ix). One of the archetypical cases was that of Marie Skłodowska-Curie (1867-1934), whose works were often considered as less important than her husband's ones. More recently, Annette Lykknes, Donald Opitz and Brigitte Van Tiggelen have problematized the bargains that collaborative couples might establish, providing a very heterogeneous set of examples which they define 'for better or for worse'. These examples, often studied through archives and correspondence, question commonplaces on the solitary genius, often a 'big man', in science, helping to put scholarship in its context by challenging historical readings which erased 'the familial infrastructure behind that genius' (Lykknes, Opitz and Van Tiggelen 2012, 6). Beyond the complexity of each empirical case, ongoing research shows numerous exceptions to the classical model understanding the husband as the leading professor and the wife as the subaltern assistant (Lykknes, Opitz and Van Tiggelen 2012, 8). The Coudreaus were an example of this exception, one which provides useful insights for addressing atypical cases like that of a scholarly non-academic couple also suffering political marginalization.

2017, "Imperial ambivalences. Histories of lady travellers and the French explorer Octavie Renard-Coudreau (1867-1938)", Geografiska Annaler Series B, 99(3), 2017, pp. 238-255 http://www.tandfonline.com/doi/full/10.1080/04353684.2017.1353887 
In the first part of my article, I provide some insights and definitions from the debates on women travellers and imperial and counter-imperial geographies to establish the theoretical framework in which I analyse Octavie's case. In the second part, I discuss her background and her first journeys to understand the complexity of her political, cultural and social contexts. In the third part, I analyse her travels 'alone', addressing issues on gender, race and feminine authority and way in which Octavie finally distanced herself from anarchist and socialist milieus.

\section{Histories of women and independent explorers}

The first exploratory essays in feminist historical geography denounced the way in which 'historical geography's ignorance of feminism has resulted at best in the marginalisation of women, and at worst in their total exclusion from the histories that are created and taught by historical geographers' (Rose and Ogborn 1988, 405). In the 1990s, the case made by David Stoddart (1991) to include exploration in histories of geographies became the basis for feminist geographers, such as Mona Domosh, to include accounts of lady travellers, arguing that they were overlooked because they were allegedly too subjective, failing to adhere to what was considered correct scientific standards. As Domosh noted: 'The stories of women travellers are incredibly diverse, yet they share some common threads, one of which is their quite explicit recognition of the personal goals of their travels. The so-called objective discoveries of new places were not separated from the discoveries of themselves' (Domosh 1991, 97). According to Domosh, women's contributions to geographic expeditions lay mainly in 'the subjectivity of fieldwork ... systematically taken out of the realm of scientific geography. The suppression of the subjective and the denial of the ambiguity of observation was part of the legitimation of the academy and the professionalization of the social sciences that occurred in the first half of the twentieth century' (Domosh 1991, 99). A classic example of this was the long struggle over the admission of women as members of the Royal Geographical Society, which lasted until 1914 after encountering a ferocious resistance from the most conservative society members (Bell and McEwan 1996). Thus, one of the reasons for women's exclusion from disciplinary accounts would have been their alleged lack of objectivity in conducting and disseminating geographical research,

2017, "Imperial ambivalences. Histories of lady travellers and the French explorer Octavie Renard-Coudreau (1867-1938)", Geografiska Annaler Series B, 99(3), 2017, pp. 238-255 http://www.tandfonline.com/doi/full/10.1080/04353684.2017.1353887 
which fell outside 'the confines of the world circumscribed by a male-defined language' (Domosh 1991, 99).

By contrast, authors such as Blunt and Gillian Rose criticised what they considered essentialist narrations 'that simply added "women's experience” to historical inquiry' (Blunt 1994a, 2). They challenged binary distinctions and generalisations to set a research agenda 'thinking about the intersection of race, gender, sexuality and class in the representation of other places and people' (Blunt and Rose 1994, 8), including the possibility that women could be imperial agents or central figures in some sectors of early institutional geography, as was the case for the Scottish geographer Marion Newbigin (Maddrell 1997). Thus, avoiding essentialism became a central point for feminist and critical research agendas in geography. Today, the stances of removing gender-based generalisations and delving deeper into the involvement of women in the history of geography are both acknowledged. Current scholarship also argues that "women remain, in various ways, marginalised in respect to male colleagues, notably in terms of gradually shifting but still marked underrepresentation in promoted posts in geography at UK universities, especially in professorial positions' (Evans, Keighren and Maddrell 2013, 374). This research also points out that there is a need to understand 'how women's gendered status and socialisation influenced their access to geographical knowledge and institutions, and in turn influenced how they saw the world geographically' (Maddrell 2009, 5). Geographers still recognise the need for 'repopulating [the history of geography] with women and providing a substantiation of their work that has been largely absent from disciplinary histories' (Maddrell 2009, 24), to recover ‘forgotten ideas and personalities' (Godlewska 1999, 9)

To avoid 'essentialism and the perpetuation of artificial binary oppositions' (Blunt 1994a, 26), I address the concept of ambivalence in a large sense, considering it as a feature characterising the in-betweenness of actors performing complex mediations in colonial contexts (Morrissey 2004). The case of Octavie Renard-Coudreau represents all this complexity, because it is possible to identify different levels of ambivalence in her works and experiences: ambivalences in terms of gendered identification, as she presented her figure of explorer in rather 'masculine' terms;

2017, "Imperial ambivalences. Histories of lady travellers and the French explorer Octavie Renard-Coudreau (1867-1938)", Geografiska Annaler Series B, 99(3), 2017, pp. 238-255 http://www.tandfonline.com/doi/full/10.1080/04353684.2017.1353887 
ambivalences in terms of social identification, because she considered herself to be part of the 'proletarians' in Europe, but represented indeed the colonial bourgeoisie in indigenous and AfroBrazilian lands; ambivalences in terms of civilizational status, as she defined herself a 'civilised' but wanted equally to be a 'savage'; ambivalences in terms of relations with the Empire, as she was acquainted with both indigenous people and the 'internal colonisers' of Brazilian institutions, while remaining a French and French-speaking scholar in years of acute French-Brazilian imperial rivalries. This confirms the need to combine 'feminist and contextual readings of the historiography of geography in order to consider the "place" or complex location/s of the women working in geography in the nineteenth and early twentieth century' (Maddrell 2009, 8).

Another example of this ambivalence is exemplified by the concept of tropicality. This idea was a part of Brazilian national myths, elaborated in original ways during the twentieth century such as in the case of Lusotropicalism (Morier-Genoud and Cahen, 2012). Working on Brazilian architect Roberto Burle Marx's realisations, Nancy Stepan has shown that claims for Brazilian national identities were based on versions of tropicality intended not as synonymous with nature and archaism, but as a specific form of modernity, exemplified by Oswald De Andrade's claim to 'transform the taboo into a totem, reversing Freud's prescription to turn a totem into a taboo and thereby achieve civilisation through repression' (Stepan 2000, 87). Likewise, this hesitation between archaism and modernism could well represent the ambivalence of the Coudreaus towards the idea of modernity.

Empire remains a fundamental analytical category. It is worth noting that empire informed the endeavours of female travellers not only in the context of Victorian Britain. For instance, Mona Domosh and Joni Seager observe that many American women participated in travels that could be defined as imperial, as they were at the same time 'explorers, imperialists, geographers and ladies' (Domosh and Seager 2001, 143). Many others served European colonial powers for which 'a sizable group of women also travelled into colonial regions and returned with information that was used to legitimate and promote colonialism' (Domosh and Seager 2001, 144). In the case of Octavie, this occurred outside direct imperial involvement because she was marginalised in the

2017, "Imperial ambivalences. Histories of lady travellers and the French explorer Octavie Renard-Coudreau (1867-1938)", Geografiska Annaler Series B, 99(3), 2017, pp. 238-255 http://www.tandfonline.com/doi/full/10.1080/04353684.2017.1353887 
French context, as her husband was also one of the people (indirectly) responsible of the loss of the territory disputed between France and Brazil in 1900 (Ferretti 2015).

In the case of Amazonia, a field object of the famous travels by Alexander von Humboldt and Robert Hermann Schomburgk, Luciana Martins demonstrated the evocative power that this region still exercised on the Western colonial imagination in the $20^{\text {th }}$ century. Eventually, women took their place in the exotic construction of this tropical otherness, including the famous explorer and filmmaker Aloha Baker, eager to display indigenous people, defined as 'simple children of nature' (Martins 2007, 289), to Western publics. Another feminine presence in twentieth-century North American expeditions to Amazonia was the wife of explorer Alexander Hamilton Rice, Eleanor Rice, who was defined by the US press in 1917 as 'the first woman to explore parts of Amazon wilds' (Martins 2007, 296). This demonstrates not only that Octavie Coudreau remained completely unknown to the history of exploration but also the long-lasting prejudices that resulted in surprise at a woman assuming 'masculine' tasks. In the history of exploration, her experience, like that of her husband (Ferretti 2017), contributes to better understand several points raised by recent literature in the history of explorations, interested in the contact zones between 'explorers' and 'explored', theatre of 'quotidian encounters with other peoples' (Kennedy 2014, 8). Matching Dane Kennedy's arguments, Simon Naylor and James Ryan argue that contemporary scholarship challenged both readings on the 'heroic' discovery and foci limited to mere textual analysis of travel literature. These authors consider four main approaches for histories of exploration: 'First, exploration and the production of knowledge; second, exploration and the processes of cultural contact and exchange; third, the textual and pictorial representation of exploration; and, lastly, biographical studies of explorers' (Naylor and Ryan 2010, 2). While I try for the first time a biographical scholarly work on Octavie Renard, my focus here is mostly on her contacts and exchanges with the local peoples, both 'indigenous', Afro-descendants and Brazilian Euro-descendant bourgeoisie.

Finally, if the imperial context facilitated the travel of British women (Blunt 1994a; Maddrell 2009), the case of Octavie Renard-Coudreau present at least two main originalities. First, she was

2017, "Imperial ambivalences. Histories of lady travellers and the French explorer Octavie Renard-Coudreau (1867-1938)", Geografiska Annaler Series B, 99(3), 2017, pp. 238-255 http://www.tandfonline.com/doi/full/10.1080/04353684.2017.1353887 
not directly connected with a European empire, despite claiming a French identity and intellectual tradition. Second, her example provides a different viewpoint (French and Brazilian) than the Anglo-Saxon one, which is rather hegemonic in this literature, and contributes to the scholarship addressing tropical worlds as places of 'disturbance' for Western travellers' intellectual tools (Driver 2004).

\section{A strange lady explorer and her husband}

Octavie Renard was born to an agrarian bourgeoisie family in Anais, Charente region, in southwestern France. As was increasingly common among her generation of French women, she was educated and started to work as an institutrice, i.e., a schoolteacher, inserted into the new system of public and secular school instituted by the Third Republic. According to the first biographer of the couple (though his book is dedicated to Henri), Max Mouchet, Octavie met Henri Coudreau during his stay in Paris while publishing his major work, Chez nos Indiens (1893), in which he described his extended visit within the indigenous communities between Brazil and French Guiana from 1887 to 1891 . Coudreau was and remains a rather controversial figure (Benoit 2000), but little scholarly work has been produced trying to clarify his complex mix of anarchism, Saint-Simonianist socialism, Rousseanism and European racial prejudices. In any case, he was an 'irregular' who deserted his institutional mission to follow his own political agendas. He was officially declared persona non grata in the territory disputed by France and Brazil due to his support for an independent Amazonia, leading to his political disgrace despite the commercial success of his books. When he sought a new appointment, the French Ministry of Colonies refused to him (Ferretti 2015).

Despite having grown up in a conservative Catholic milieu, Octavie agreed to marry Henri in a civil ceremony in 1893. According to Mouchet, Octavie would gradually embrace Coudreau's atheism and later develop a sort of spiritism after her return to France (Mouchet 1973, 163), inspired by Amazonian religions. In the same year, Coudreau managed to obtain funding from

2017, "Imperial ambivalences. Histories of lady travellers and the French explorer Octavie Renard-Coudreau (1867-1938)", Geografiska Annaler Series B, 99(3), 2017, pp. 238-255 http://www.tandfonline.com/doi/full/10.1080/04353684.2017.1353887 
the Ministry of Education for a 'geographic and ethnographic expedition' (Benoit 2000, 116) ${ }^{1}$ on the Oyapock river despite the opposition of the Ministry of Colonies, and Octavie decided to accompany her husband. This mission of 1893-94 is the only one that the Coudreaus did not document through their travel books, a fact that led some commentators to the suspect that Henri Coudreau was working as a 'secret agent' (Benoit 2000, 110). Indeed, the only thing that is clear from the available sources is that Octavie did not fit the classic role of the white bourgeois wife following her 'heroic' husband. Instead, she indirectly took the direction of this trip. After more than a decade of what he called 'savage life' in Amazonia, Henri's health had already been seriously compromised by tropical fevers (such as malaria) that left him periodically in state of weakness and feeble lucidity. According to his biographers, he had also problems with a dependence on alcohol. The Guiana French governor stated: 'Following certain excesses, Mr. Coudreau no longer has the intellectual lucidity or the moral authority to lead such expeditions' (Benoit 2000, 118): thus, Octavie was the informal chief of mission and took responsibility for corresponding with the Ministry, who ordered the repatriation of the group in 1894.

In 1895, having been definitively marginalised in France, the Coudreaus decided to accept an appointment by Lauro Sodré, governor of the Brazilian state of Pará. At that time, Brazil was involved in its border dispute with France, which was not resolved until 1900 (one year after Coudeau's death) when the government of the Helvetic Confederation was asked to referee the dispute and decided to grant the whole territory to Brazil. This region, which extended over 300,000 square kilometres, corresponds roughly to the present-day Brazilian state of Amapa. The works of French heterodox geographers such as Reclus and Coudreau, who admitted that this region was mainly settled by indigenous people and Portuguese-speaking colons, were used by the referees as an argument against French imperial pretentions (Ferretti 2015). In 1895, Coudreau's appointment in Brazil was considered a betrayal by the French, and the explorer wrote to Elisée Reclus recalling the 1871 Paris Commune: 'The whole of the opportunistic press has accused me of the darkest infamies: lack of patriotism, no aptitude for engaging in bribes... I am now in the same mood as you in 1871 in the inner courtyard of the prison in Versailles where

\footnotetext{
${ }^{1}$ All quotes from texts in French and Portuguese have been translated by the author.

2017, "Imperial ambivalences. Histories of lady travellers and the French explorer Octavie Renard-Coudreau (1867-1938)", Geografiska Annaler Series B, 99(3), 2017, pp. 238-255 http://www.tandfonline.com/doi/full/10.1080/04353684.2017.1353887 
pretty young ladies shook the bodies of [Communards] who seemed dead with the end of their parasols to see the look in the eyes of an irregular shot down'.2

From 1895 to 1899 , the Coudreaus conducted 7 expeditions to the tributaries of the Western Amazon River, each one documented by a book published for the Parisian Maison Lahure. These works show the important role that Octavie played in surveying, drawing maps and taking photos. In fact, the 6 books written by Henri on these trips (Coudreau 1897a; 1897b; 1897c; 1898; 1899) and the others written by Octavie on the expeditions she led by herself (RenardCoudreau 1900; 1901; 1903a; 1903b; 1903c; 1906) have an abundant photographic production as one of their main features. It is worth noting that the Coudreaus seemed to be more loyal to Brazilian institutions than they were to French ones, as also shown by the unpublished correspondence of Baron Rio Branco, one of the 'Founding Fathers' of the Brazilian Republic and the winner of border disputes like the 1900 one with France (Pereira Carris Cardoso 2016). Archival research demonstrates that, in the period of the 1897-1900 Franco-Brazilian border dispute, Henri Coudreau did not support France and even corresponded with Rio Branco. ${ }^{3}$

The Coudreaus' expeditions were clearly part of the programme of internal colonialism pursued by Creole postcolonial elites in Latin America to claim lands formerly occupied by indigenous communities (Maldonado-Torres 2016; Porto-Gonçalves and Araujo Quental 2012). If Octavie admitted this by stating that she was paid to 'trace the way that the coloniser will later populate and cultivate' (Renard-Coudreau 1901, 48), her case remains an original example of European explorers operating outside (and eventually against) the interests of their own homeland, serving not another European empire but a de-colonised state of what is today the 'Global South' and was then competing against both the British and French empires for the Guianas' borders.

The relation between the Coudreaus and their homeland remained ambiguous, as they continued to publish their books in France. However, they paid the cost of their increasing marginalisation

\footnotetext{
${ }^{2}$ Paris, Bibliothèque Nationale de France (BNF), NAF 22914, H. Coudreau to E. Reclus, 18 February 1896, f. 65.

${ }^{3}$ Rio de Janeiro, Arquivos de Itamaraty, Arquivo Particular do Barão do Rio Branco (heareafter Itamaraty), Missão Coudreau, lata 821 maço 1, pasta 10, H. Coudreau to Baron Rio Branco, 25 March 1898.
}

2017, "Imperial ambivalences. Histories of lady travellers and the French explorer Octavie Renard-Coudreau (1867-1938)", Geografiska Annaler Series B, 99(3), 2017, pp. 238-255 http://www.tandfonline.com/doi/full/10.1080/04353684.2017.1353887 
in French-speaking arenas, as the name Coudreau, very famous in the period 1886-1894 and granted the Golden Medal of the Paris Geographical Society in 1892, became then rarer and rarer in French geographical journals; his obituary in the Annales de Géographie was limited to few very cold lines (Zimmermann 1900). If Coudreau's most famous book (1893) was published by the prestigious Maison Hachette, his books covering the Brazilian period, and later those of Octavie, were printed by a less famous publisher, Lahure. As I explain in the next session, gender issues will accentuate Octavie's marginalisation when she continued Amazonian exploration; no detailed book review or obituary was dedicated to her, to the best of my knowledge, by the French geographical press beyond few synthetic notes on the bulletins of French and Belgian geographical societies (Georlette 1903)

2017, "Imperial ambivalences. Histories of lady travellers and the French explorer Octavie Renard-Coudreau (1867-1938)", Geografiska Annaler Series B, 99(3), 2017, pp. 238-255 http://www.tandfonline.com/doi/full/10.1080/04353684.2017.1353887 


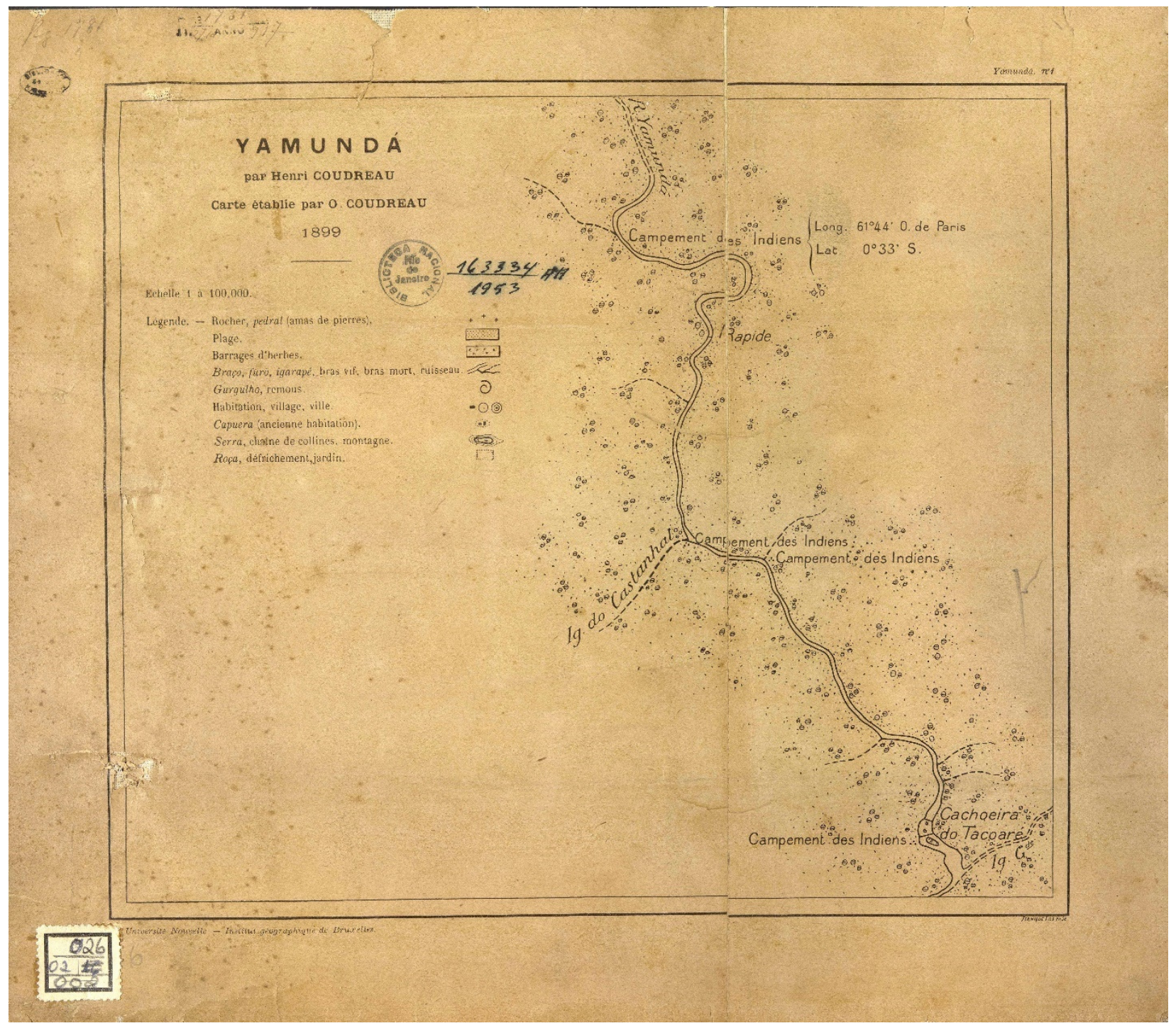

Fig. 1 - First sheet of the map drawn by Octavie Renard-Coudreau after the 1899 expedition on the Yamunda River

The exception was Elisée Reclus's Institut Cartographique at the Brussels Université Nouvelle. Reclus continued to support Henri and Octavie, releasing notices of their travels in the socialist journal L'Humanité Nouvelle and helping them to publish their works. A part of these books contained maps drawn by Octavie and engraved in Brussels by Reclus's collaborators before reaching their Paris publisher (Coudreau 1897 and 1899; Renard-Coudreau 1901). In Brazil, the couple's popularity was accordingly wider, although scholarship on their work has appeared there

2017, "Imperial ambivalences. Histories of lady travellers and the French explorer Octavie Renard-Coudreau (1867-1938)", Geografiska Annaler Series B, 99(3), 2017, pp. 238-255 http://www.tandfonline.com/doi/full/10.1080/04353684.2017.1353887 
only recently (Pereira Carris Cardoso 2015 and 2016; Souza Filho 2008). Though defining the Coudreaus as 'a couple of anarchists' (Souza Filho 2008, 12), Durval Souza Filho observes that their idea of the Tropics as a possible place for building more equitable social relations typical of certain Saint-Simonianist socialism in Europe matched the 'Brazilian national myths' (Souza Filho 2008, 29) as explained above. This also confirms the importance of the invention of a Brazil's geographical image in the process of nation building (Murari 2007).

The Coudreaus were also sensitive to the problems of interethnic dialogue, considering Henri's (and on less extent Octavie's) skills in several Indian languages. In his last years, Coudreau, a strong defender of Indian communities against the crimes of the 'civilisers' (Coudreau 1887 and 1893), argued against slavery and 'civilisation, which appeared here under its mercantile form' (Coudreau 1897b, 75). Thus, one of the aspects of Octavie's travels was a certain degree of empathy and direct dialogue with local communities, which is not always easy to find in the experiences of American and British lady travellers studied by current literature apart from some women committed to missionary endeavours, such as Isabella Bird and Mary Slessor (Maddrell, 2009).

It is possible to conclude that Octavie's background is paramount to understanding her cultural and political ambivalences, as both radical and conservative inputs coexisted in her personal trajectory. In the next section, I analyse her autonomous travels while first addressing her attempts to deny and 'hide' her gender and then the political aspects of her attitude towards indigenous communities, Indians, Afro-descendants and creole Brazilians.

\section{Travelling 'alone'}

\section{1 'Explorateur' or 'exploratrice'?}

On 9 November 1899, Henri Coudreau died in the forests on the shores of the Portera River while travelling with his wife and the eight men of the Brazilian crew who accompanied his last expedition in the region of the Trombetas River. Once Henri was buried, Octavie, universally

2017, "Imperial ambivalences. Histories of lady travellers and the French explorer Octavie Renard-Coudreau (1867-1938)", Geografiska Annaler Series B, 99(3), 2017, pp. 238-255 http://www.tandfonline.com/doi/full/10.1080/04353684.2017.1353887 
known as Madame, did not hesitate to take her husband's role and lead the last part of this expedition. In the following years, from 1900 to 1906, she undertook other five expeditions on behalf of the states of Pará and Amazonia, publishing all of her reports in the form of illustrated books in French. The initial note she wrote to justify her first independent journey is indicative of the intricacy of gender roles that, according to Blunt, should 'not be seen in essentialist terms but rather as constructed and contested in many different ways over space and time' (Bunt 1994a, 8). In French, the world explorer, explorateur, is susceptible to being feminised as exploratrice (woman explorer); Octavie's first act as an independent exploratrice was to explicitly deny this feminisation, defining herself as an explorateur. 'If I am an explorateur (a word impossible to feminise), it is not for Glory, a goddess even blinder than Fortune, and not, with apologies to my friend Elisée Reclus, for love of geography; I think that I will love geography more when I no longer do it. If I explore, it is to have the means for bringing the remains of my husband to his old parents, to not leave Henri Coudreau forever in a stranger (though friendly) land, and to complete the work we started five years ago, which is most useful because it consists of making known lands still unknown by the masses' (Renard-Coudreau 1901, 1).

Thus, Octavie seemed to justify her assumption of such a role by denying even the possibility of a female explorer; in fact, she considered herself to have become an explorateur, a male, but just temporarily and for material needs, i.e., earning enough money to lead an expedition that could recover Henri's remains and bring them to his old parents. This task, which implied the concepts of wifely devotion and the association between the woman and the ancestral house, rendered the idea of a French lady wandering in the Amazonian forest at the head of a group of subservient (black and brown) men clearly more acceptable to the average French reader. This image was reinforced by the recourse to an extreme argument: Octavie argued that she did not love geography at all, apologizing to the symbolic figure of Reclus, the most famous French geographer of that day and the last advocate of her husband in the discipline.

However, evoking Reclus also meant opening possibilities, and claiming his friendship was an implicit admission of a link with geography. This is even truer if we consider that this friendship

2017, "Imperial ambivalences. Histories of lady travellers and the French explorer Octavie Renard-Coudreau (1867-1938)", Geografiska Annaler Series B, 99(3), 2017, pp. 238-255 http://www.tandfonline.com/doi/full/10.1080/04353684.2017.1353887 
was not alleged but real; Reclus's unpublished correspondences demonstrate that the anarchist geographer helped Octavie publishing her books and maps for Lahure. In 1901, Reclus wrote to a collaborator [probably Emile Patesson] that 'Mrs. Coudreau wants us to reproduce in colours her new map of the Cuminá River ... including 18 sheets for which we will use four colours: black for the trait; blue for the major rivers, green for the woods and red for huts and trails'. ${ }^{4}$ This map was then included as a supplement to Octavie's Voyage au Cuminá. As of April 1903, the elderly Reclus was still preoccupied with the fate of Madame Coudreau and asked his Parisian editor Charles Schiffer to seek information on her. 'I am sorry for the time you spent in searching fruitlessly for Mrs. Coudreau. Anyway, if you hear at Lahure's House that she appeared, please inform me... It is there that she may bring her new work unless she is sick, desperate, or lost. Her last letter was very disquieting, ${ }^{5}$ It would be too easy to see a paternalistic attitude towards a 'weak' woman in Reclus's behaviour, but this was not the case because Reclus was acquainted with early French feminists and women who fought in the Paris Commune, such as Louise Michel (Ferretti 2016b), and as I explain below, Octavie was not weak at all. Indeed, some adventures she recounted would be frightening to anyone (Renard-Coudreau 1903a; 1903b; 1903c). What Reclus finally endorsed was Octavie's legitimacy and the authority of her reports, giving credibility to her final claim, which clashed with her earlier denials of being a 'true' geographer-explorer: 'I can accomplish the task that is entrusted to me because Henri Coudreau, whose name I am proud to hold, with his fair indifference to questions of money, has left to me [no money but] the necessary knowledge to make an accurate geographical survey' (RenardCoudreau 1901, 1). These claims contradicted 'patriarchal constructions of women as weak and inferior' (Blunt 1994a, 1). Octavie's accomplishments as a map-maker demonstrated that she was even more skilled than her husband in conducting what Burnett defined the 'traverse survey' as opposed to the 'trigonometric survey' (Burnett 2000, 10). Henri did not produce cartographic output drawn by himself, leaving that responsibility to his wife. This sheds new light on common assumptions about map-making as an essential masculine task, such as Blunt's observation that:

\footnotetext{
${ }^{4}$ Private collection, E. Reclus to [E. Patesson] [1901], http://www.chapitre.com/CHAPITRE/fr/BOOK/elisee-reclusprepare-la-publication-d-un-recit-de-l-exploratrice-octavie-coudre/lettres-autographessignees, 61019257.aspx\#offerlistings

${ }_{5}^{5}$ Bibliothèque Publique et Universitaire de Neuchâtel (BUPN), MS 1991/10, E. Reclus to C. Schiffer, 30 April 1903.

2017, "Imperial ambivalences. Histories of lady travellers and the French explorer Octavie Renard-Coudreau (1867-1938)", Geografiska Annaler Series B, 99(3), 2017, pp. 238-255 http://www.tandfonline.com/doi/full/10.1080/04353684.2017.1353887 
'Mary Kingsley's reluctance to map her route seems symptomatic of her tenuous identification similar to, but different from, male explorers' (Blunt 1994b, 52).

Nevertheless, Octavie's reasons for travelling seemed to lie in the complex intersections of economic, intellectual and intimate motivations, including the attraction she felt for the so-called savage life and her difficult re-adaptation to 'civilised' life, a romantic view that she shared with Henri. 'I fled, as I wanted to escape from the civilised life and live again in my favourite environment where there is no longer anybody nor anything, and the administrated and policed world is very far. The solitude of virgin forests became a need for me' (Renard-Coudreau 1903a, 1). If this use of the term 'virgin' recalls a masculine vision of lands to 'discover' and 'fecundate', many intimate reflections are proposed in Octavie's books related to her feelings and her moral suffering in opposition to the stereotypes of the 'heroic' explorer. During the first night of her first travel without Coudreau, Octavie wrote: 'I am in the same house, I sleep in the same room that we occupied together during the expedition to the Trombetas River. I withdraw more and more into myself, and my soring spirit is overwhelmed by loneliness' (Renard-Coudreau 1901, 7). Similar remarks are re-proposed during moments of rest when her thoughts assaulted her more often than during marches: 'Today it is holyday for my men, but for me, it implies a sad coming back to myself. Alone - alone to support the sadness of life. But why then complaining and crying? Tears never resolved the infortunes ... this is not in my disposition; it is better to raise your head and march fiercely with dry eyes and clamped teeth' (Renard-Coudreau 1903b, 64). It is worth noting that feelings and subjectivity likewise existed in Henri's writings, thus these subjective aspects are not necessarily indicators of gender difference. Moreover, Octavie tried to censor these feelings through the ethics of work. 'My sadness has to remain silent: philosophical reflections do not have value for explorers ... the activity, work and overburdening that I impose on myself will be my safety' (Renard-Coudreau 1903c, 74-75).

Nevertheless, gender remained a major issue. A characteristic of Octavie's books, as in other cases of lady travellers, was her semi-anonymity, as they were always signed 'O. Coudreau' rather than with her full name. Only by knowing the story or reading the entire book could the

2017, "Imperial ambivalences. Histories of lady travellers and the French explorer Octavie Renard-Coudreau (1867-1938)", Geografiska Annaler Series B, 99(3), 2017, pp. 238-255 http://www.tandfonline.com/doi/full/10.1080/04353684.2017.1353887 
French reader guess that this explorateur was actually an exploratrice. This is still the source of amazing confusion in the catalogues of the French National Library, where Octavie is still an unknown author, as her books are often inventoried as 'O. Coudreau' or attributed to Henri. In the catalogue of the main Brazilian university, the USP, she is recorded as 'Odette' (Trimer 2009). The choice of hiding the author's gender was accordingly a commercial one because the travel reports of a lady were less likely to convince the public of their 'authority', strictly linked to the concept of 'authorship' in explorers' accounts (Withers, Keighren and Bell 2015). The issue of credibility is also raised by an anecdote reported by Mouchet, who claimed that Octavie, during her travel at the Maycuru River, was taken prisoner by a hostile tribe and managed to escape during the night in daring circumstances, taking advantage of her jailers' sleep (Mouchet 1973, 157). However, no trace of this episode is contained in Octavie's books. Therefore, this might be an invention by the author or his indirect witnesses, as Mouchet's book is widely based on the recollections of Henri's younger brother and brother-in-law furnished 'between 1942 and 1944' (Mouchet 1973, 1). This episode could not have been included in the book as it would have rendered the story too implausible for a 'weak' woman, but might have survived in her family's memory. Anyway, Octavie was more likely to seek legitimation by demonstrating that she was an intellectual person, writing in excellent French prose and sometimes raising the scientific debates of her time with references to key authors, such as her remarks on the discovery of moraine pebbles, leading her to suppose that 'there could be something right in Agassiz's theory of a glacial period in Amazonia' (Renard-Coudreau 1903c, 71).

Even a very sympathetic biographer such as Mouchet could not escape gendered stereotypes. In a drawn representing the death of Coudreau assisted by his wife (Mouchet 1973, 151), the imagined nakedness of Octavie, represented as an Indian woman, likely a sorcerer, contrasts with the severe European aspect of the dying Coudreau, while according to the respective travel reports, these roles should have been reversed. In fact, Henri was the only one who stated that he had experimented customary nakedness while living with Indian communities before marrying Octavie; he also alluded to sexual experiences he might have had during these sojourns (Coudreau 1887 and 1893). Octavie's prose was remarkably more disciplined. During her travels

2017, "Imperial ambivalences. Histories of lady travellers and the French explorer Octavie Renard-Coudreau (1867-1938)", Geografiska Annaler Series B, 99(3), 2017, pp. 238-255 http://www.tandfonline.com/doi/full/10.1080/04353684.2017.1353887 
after Henri's death, Octavie was the only woman within the expeditionary groups of 6-8 people with the crew members being young Brazilian men, while she was still a young widow. Nevertheless, in her accounts, she seems to censor any form of eroticisation in her experience, at least in terms of her own involvement. When she had physical contact with these men, it was most often in her role as the group's nurse; she always referenced the metaphor of 'maternal care'. Paradoxically, it was still with a male eye, such as that of her husband, that Octavie observed the 'spectacle' of naked Indian girls, reproducing stereotypes of women and nature in her idea that robes would contaminate that wild and 'exotic' beauty (Staszak 2008). 'A dozen women and young girls are gathering to have a bath ... According to the country's customs, they are naked and believe me, they are really pretty without their clothes, a fact which one would not notice if they were dressed' (Renard-Coudreau 1903a, 13).

Ambivalence concerning gender roles likewise emerged in the relations with indigenous tribes. Questions such as 'but are you really a woman?' (Renard-Coudreau 1903a, 4) were not unusual for Octavie, who always travelled heavily dressed in masculine clothes. Sometimes, groups of indigenous women and children, generally fleeing the gaze of the explorers, felt reassured when Octavie was recognised as a woman. The chiefs, once aware of Octavie's gender, also sometimes felt more confident. 'This old chieftain examines me ... he opens my jacket and was struck at seeing my shirt-you know, I wear two shirts and he does not have one. He wants to take my knife, but his hand meets a feminine breast; he brings back his hand, closes my jacket and says: but you are a woman. Yes, my friend I am a chief woman, an old woman - I answer. It is only now that he is sure that I am a woman, he now trusts me. An unknown woman inspires confidence in a savage, while the civilised deem us "perfidious like sea waves" (perfides comme les ondes)' (Renard-Coudreau 1901, 158). This mention of a masculinist proverb is one of the rare explicit critiques of patriarchy that one finds in Octavie's work. It is possible to compare these episodes with Cheryl McEwan's remarks on white women who were more easily accepted than men in West Africa because they 'presented little threat to authority of African men; their status as women facilitated easy and frequent access to African women' (McEwan 1994, 76). Nevertheless, this comparison seems to work more for Octavie's relations with men, while her

2017, "Imperial ambivalences. Histories of lady travellers and the French explorer Octavie Renard-Coudreau (1867-1938)", Geografiska Annaler Series B, 99(3), 2017, pp. 238-255 http://www.tandfonline.com/doi/full/10.1080/04353684.2017.1353887 
relations with local women are rarely addressed in her works, and she seemed to not consider them as one of the more interesting topics. In only a few circumstances, Octavie had the occasion to talk with women who approached her, perceiving that she was not a danger to them, like in the voyage to Canumã where two Indian girls said to her, "with a sadness in their voice - one has always to fear the seringueiros' (Renard-Coudreau 1906, 60), that is, the 'civilised' men working to extract rubber, alluding to rapes and murders perpetrated by them.

Something similar to an inversion of gender roles was also evoked by Octavie in matters of carrying weapons and providing security for the group in case of danger: 'We are only five men including myself. What could we possibly do if assaulted during the night?' (Renard-Coudreau 1903c, 99). Octavie did not only define herself as a 'man', but also criticised the alleged lack of 'virility' of her crew. 'João is as fearful as I never imagined a man could be. In the night, he puts the lantern very close to his hammock fearing that the jaguar could come take him, and he smokes to keep from falling asleep' (Renard-Coudreau 1903c, 125). For Octavie's last expedition in 1906, 'every man has his extra equipment: one Winchester, bullets, a machete. I have my (useless) revolver, my knife, my compass, my notebook, a pedometer attached to my feet' (Renard-Coudreau 1906, 74). The masculinisation of the explorer's figure is hardly surprising for that time when also considering cases such as that of Mary Kingsley defining herself as 'the third Englishman' (Blunt 1994b, 59) to ascend Mount Cameroon in Africa. Thus, Octavie Renard was still an example of the ambivalence that other female travellers represented with some strong efforts to more look like a man, which seems to be justified more by her own ideas than by a social pressure coming from Europe, hardly much influential on her works of 1899-1906.

\subsection{Gender, race and 'maternal' authoritarianism}

As noted in the aforementioned studies, gender roles overlap with class and race issues, conferring to women travellers more authority than they would have in their respective homelands. It is worth noting that Octavie was especially willing to exercise her authority on her crew and maintain it through threats and physical violence towards those she found guilty of infractions, which her husband had always refused to do. As Octavie argued, '[Henri's] delicate

2017, "Imperial ambivalences. Histories of lady travellers and the French explorer Octavie Renard-Coudreau (1867-1938)", Geografiska Annaler Series B, 99(3), 2017, pp. 238-255 http://www.tandfonline.com/doi/full/10.1080/04353684.2017.1353887 
nature, his high spirit, his exaggerated philanthropy was not so well fitted to the brutality sometimes necessary to deal with these unruly temperaments. Today, it is José who needs to be told off. He will remember my reprimand' (Renard-Coudreau 1901, 51). In fact, when Octavie stated that her men 'know how I usually deal with people who anger me' (Renard-Coudreau 1903c, 54), she referred to the possibility that she would beat her men as a punishment. 'While the others go hunting, I tell José to remain with me. He is nervous; when he sees that I take a machete and go to the woods to cut a large liana, he suddenly understands that it is for him. In fact, I give him a correction worthy to remain in his memory. A moment later, I regret having beaten him so violently and say to him: "Did I harm you? But was it not your fault? Did not you deserve this punishment?" "No," he answered smiling, "Lady did not harm me. ${ }^{6}$ A mother always hits her son with love"" (Renard-Coudreau 1901, 55). Thus, such authoritarianism remained in a family-like atmosphere, like a maternal version of colonial paternalism that was based on the infantilization of Octavie's men, joined to their racialisation. For instance, Octavie described her feelings during a night in the forest. 'My sailors chat and eat almost all night; they talk of futilities, I love their childishness' (Renard-Coudreau 1901, 111). A paternalist (or maternalist) racialisation appears clearly in statements like: 'My heart is indulgent with these Blacks who served my husband and who now serve me so faithfully' (Renard-Coudreau 1903a, 28). This did not exclude specific feelings for some individuals, as Octavie talked to her men more frequently as individuals than as group and expressed clear preferences for some of them, such as two brothers, Chico and Estevão, who followed the Coudreaus for many years. 'Estevão is one of those that I like most' (Renard-Coudreau 1903c, 82). However, her authority was ultimately guaranteed by the assertion of force, demonstrated by her preliminary discourse to the crew before leaving for the last expedition: 'You must do everything I command without discussion ... in case we meet Indians, you are forbidden from fleeing or else I will shoot you' (RenardCoudreau 1906, 6).

\footnotetext{
${ }^{6}$ The sentences pronounced in third person are not caricatures, but Octavie's literal translation from Portuguese normal phrasing (e.g. A senhora não fez ....).

2017, "Imperial ambivalences. Histories of lady travellers and the French explorer Octavie Renard-Coudreau (1867-1938)", Geografiska Annaler Series B, 99(3), 2017, pp. 238-255 http://www.tandfonline.com/doi/full/10.1080/04353684.2017.1353887 


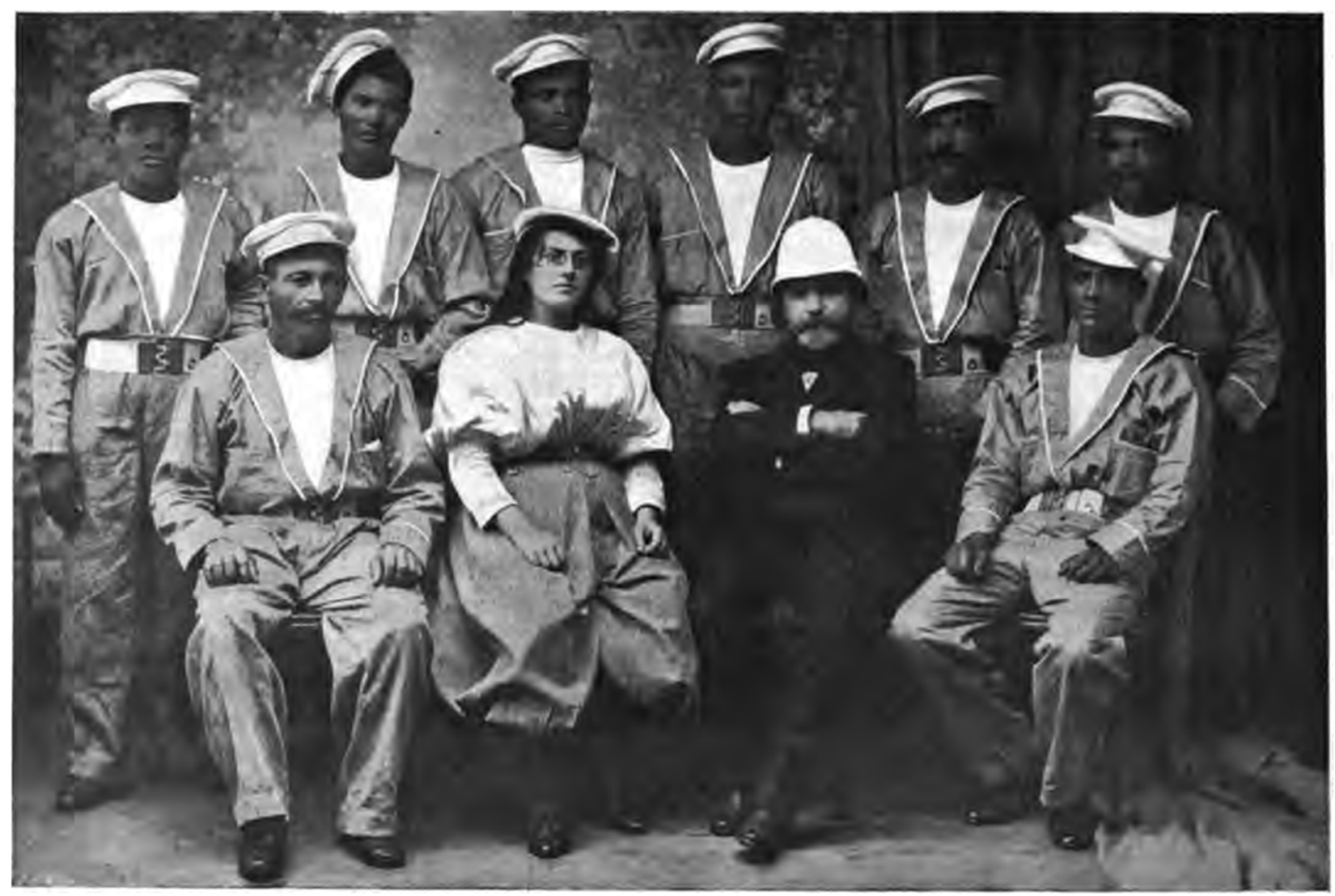

Fig. 2. The Coudreaus with the crew that Octavie would later lead (Renard-Coudreau, 1900)

Octavie also became involved in local political issues, thanks to her command of Portuguese and her acquaintance with local politicians. In this field, she often evoked enemies and jealousy, showing the strength of her personality and her willingness to fight for her position of 'state explorer'. She stated that after the changing of the local government, 'Mr. Montenegro, the new governor of Pará, entrusts me with a new mission to the great astonishment and disappointment of those who believed that I was already fired and were curious to know how would I have done without money or work' (Renard-Coudreau 1903b, 2). One of the political aims of her expeditions on the Amazon's tributaries was the opening of possible ways for a hypothetical Brazilian agricultural and political penetration. Octavie inquired as to the potential sources of wealth present in the region and focused on the rubber that could 'assure prosperity for Pará' (Renard-Coudreau 1903a, 108). She seemed to still share some of the socialist views of Henri,

2017, "Imperial ambivalences. Histories of lady travellers and the French explorer Octavie Renard-Coudreau (1867-1938)", Geografiska Annaler Series B, 99(3), 2017, pp. 238-255 http://www.tandfonline.com/doi/full/10.1080/04353684.2017.1353887 
criticizing the exploitation of the workers of the seringas (extraction of rubber), a sector outside legal regulation, and highlighting the hostility she faced from local entrepreneurs in her role as delegate of the local government, as they 'fear that I will seize their possessions, or that I will ask the government to tax them, which would be justice' (Renard-Coudreau 1903b, 156). These years observed the peak of the Amazonian rubber boom, and on the side of Brazilian institutions, explorers such as Octavie represented a potential asset to regulate and tax such activity. Octavie's last expedition was authorised by Constantino Nery (1859-1926), governor of the State of Amazonas from 1904 to 1908 . He did so during her 1905 visit in Manaus after they had first met in the federal capital Rio de Janeiro, where Octavie sojourned for a while (Renard-Coudreau 1906, 3). It is unclear whether Octavie's definitive return to France in 1906 was due to the accomplishment of the personal mission that she declared at the beginning, i.e., returning her husband's remains or due to the political turnover that removed her political protectors from office. The second hypothesis is reinforced by her note arguing that: 'In 1903, while I started my exploration despite being affected by beriberi, the governor of the Pará state, who I had served for 9 years, forgot to tell me that the state finances would no longer support having an official explorer ... I felt therefore obliged, not according to Brazilian law but according to the laws of justice, to pay my crew with my own money. What a legend the explorers' benefits!' (RenardCoudreau 1906, 4). Moreover, Brazilian archives show that Octavie experienced some political marginalization also in republican Brazil. In 1904, she wrote to Baron Rio Branco requesting an interview with him in Rio de Janeiro and her two letters, significantly signed ' $O$. Coudreau, explorateur' leaving again her gender implicit, were apparently not responded by the Brazilian Minister ${ }^{7}$.

The most outdated and unsettling of Octavie's discourses are a series of uncharitable racialist remarks on the black and mixed populations settling the Amazonian rivers, which contrasted with her admiration for Indian tribes and her complaints about 'civilisation'. She argued that the members of these groups 'seem to me a bit lazy, very careless and improvident; they are not concerned by the idea of future: the river will be always there to allow them to keep some fish,

\footnotetext{
${ }^{7}$ Itamaraty, lata 821, maço 01, pasta 11, O. Coudreau to Baron Rio Branco, 3 and 11 May 1904.

2017, "Imperial ambivalences. Histories of lady travellers and the French explorer Octavie Renard-Coudreau (1867-1938)", Geografiska Annaler Series B, 99(3), 2017, pp. 238-255 http://www.tandfonline.com/doi/full/10.1080/04353684.2017.1353887 
and the manioc will anyway grow with minimum work' (Renard-Coudreau 1903c, 20). This matched Octavie's remarks on the Mucambeiros, descendants of the ancient communities of Maroons, to whom she attributed 'laziness and drunkenness' (Renard-Coudreau 1903a, 18), charging them with 'corrupting' the 'pure' Indians (a clear reference to Rousseau's idea of the noble savage) by teaching them 'dishonesty and lies' (Renard-Coudreau 1903b, 159). However, some statements about these peoples recalled the most frightful racist commonplaces, such as Octavie's description of 'a big Black, more similar to the gorilla or to the chimpanzee than to the civilised man' (Renard-Coudreau 1903a, 22). In the rivalries among different communities, Octavie clearly took sides with the Indians, as demonstrated by her severe reprimand to her men when they made a statement that she quoted in the original Portuguese and triggered her rage. "Indio não é gente, é bicho do mato (Indians are not people, they are forest beasts)" (RenardCoudreau 1901, 52). Nevertheless, Octavie somewhat admitted her prejudices and introduced some elements of relativism, arguing about the Mucambeiros: 'I should admit that I judge them from my civilised standpoint, with my preconceived ideas belonging to our social conventions. I am perhaps unjust to them because ultimately can one expect the same quality of different races?' (Renard-Coudreau 1901, 178). Nevertheless, these judgements seem to belong more to cultural essentialism than to biological racialism. Contemporary scholarship has shown that the construction of racialized mappings and essentialist stereotypes occurred in different periods of history, including recent times where it is no longer question of biological racism (Livingstone 2010, Nash 2015). Nevertheless, it is important to notice the distance between Coudreaus's claims to miscegenation and the pretention of racial purity then expressed by the representatives of scientific racism (Coquery-Vidrovitch 2003; Reynaud-Paligot 2006). Octavie's appreciation of miscegenation was frequently expressed: 'Two pretty girls show again that the miscegenation of a white man and an Indian woman gives results of full beauty' (Renard-Coudreau 1901, 7). Though reproducing there gendered stereotypes (nothing is said about the miscegenation from an Indian man and a white woman) Octavie matched not only somehow Reclus's ideas of universal miscegenation as a programme to abolish racism, but also contrasted with experiences of Victorian travellers where 'miscegenation could not be sanctioned' (Blunt 1994, 29).

2017, "Imperial ambivalences. Histories of lady travellers and the French explorer Octavie Renard-Coudreau (1867-1938)", Geografiska Annaler Series B, 99(3), 2017, pp. 238-255 http://www.tandfonline.com/doi/full/10.1080/04353684.2017.1353887 
Octavie continued her husband's appraisal of the Indians' way of life, though she was less radical than Henri with his rebuttal of civilisation and comparison between Indians communities and political anarchism (Ferretti 2017). Though with different nuances, the unruly nature of these communities that impassioned Henri were likewise observed with interest by Octavie: 'These Indians absolutely do not obey; they even ignore the chiefs. Everybody does what he wants, and women especially do what they are comfortable with. I believe that anarchy rules in the maloca [Indian barrack serving sometimes the entire village community]' (Renard-Coudreau 1903b, 88). Regardless, statements on the political responsibilities of civilisation remain in Octavie's works. 'The shy civilised man has his rifle, the scared Indian has his bow and his poisonous arrows ... a minimum movement, a misunderstood gesture are enough to let the arrow start on the one side, and respond with lead. And here you are, a tribe that was peaceful before the civilisers' arrival was pushed to become brava [hostile Indians]' (Renard-Coudreau 1901, 51-52). It is possible to conclude that Octavie's views of Indian tribes, though more conservative than Henri's, still echoed Rousseau and the 'noble savage', as shown by the expectations she had prior to beginning the exploration of the Urubu River during her last expedition. 'There should be Indians who never have contact with the civilised; for centuries, magnificent legends should be told by fathers to sons. What ideas should they have about these white devils who come killing them! I would feel an intense joy in studying these primitives before our hypocrite civilisation goes to deflower and spoil them' (Renard-Coudreau 1906, 13). In this sense, the stereotypes of the feminine attributes of 'nature' and the masculine ones of 'civilisation' are presented, but with an emphasis on the latter's violence.

\section{Conclusion}

If, as Blunt argued, 'the mobilisation of constructions of gender difference over space, but the coexistence of masculine and feminine identities highlights ambivalence rather than fixed, centred constructions of otherness' (Blunt 1994b, 61), the case of Octavie Renard-Coudreau confirms that the ambivalence of lady travellers in the Age of Empire is only partially explained by issues of gender. It was also complicated by issues of social position, 'race' and political belonging. In this case, it matched the ambivalence of the European progressive world and

2017, "Imperial ambivalences. Histories of lady travellers and the French explorer Octavie Renard-Coudreau (1867-1938)", Geografiska Annaler Series B, 99(3), 2017, pp. 238-255 http://www.tandfonline.com/doi/full/10.1080/04353684.2017.1353887 
especially of French Enlightenment universalism, facing its contradictions when the declaration of human rights had to be applied outside Europe, as the case of Haitian Revolution demonstrated (Buck-Morss, 2009). It also matched the ambivalence of the decolonised creole bourgeoisie of Brazil, claiming an indigenous identity while pursuing the agenda of the 'coloniality of power' by expanding their territory at the expenses of Indian and Afro-descended communities (Mignolo 2000), with which the Coudreaus were associated despite Henri's original claims against civilisation.

Considering the aforementioned works on collaborative couples in the history of science, it is possible to conclude that the interaction between Henri and Octavie Coudreau was more 'for better' than 'for worse', as it clearly bolstered the scholarly production of both explorers. Octavie's case was characterised by the fact that her agency (though under a semi-disguised name) emerged when she remained alone, joining the numerous cases in which female scholars (including Marie Curie) found themselves highly productive in widowhood (Lykknes, Opitz and Van Tiggelen 2012, viii). Another characteristic of Octavie was doubtless her willingness to take leading and 'muscular' roles, including during her husbands' last years, when Henri Coudreau's health was already compromised and Octavie had accordingly to manage 'his' expeditions.

Gender can only partially explain why Octavie never became famous, unlike other lady explorers such as Mary Kingsley. The fact that she tried to hide her identity might have been part of a commercial strategy that she concocted with her publisher (though no sources confirm this hypothesis), but it seemed to also belong to her conservative imprinting, which finally impeded her comfort in (male) explorer's clothes. It is worth noting that her origin within the French rural middle classes and her training as a schoolteacher put her relatively apart from the elite of the 'highly educated, socially and economically privileged' (Maddrell 2009, 35) women who undertook travel in the same years. Concerning the question often included in histories of women travellers addressing the ways in which they were 'different from their male peers' (Domosh and Seager 2001, 144), I would argue that Octavie Renard was 'differently different' because though she brought an amount of subjectivity to her work, she strove for 'scientific objectivity' by trying

2017, "Imperial ambivalences. Histories of lady travellers and the French explorer Octavie Renard-Coudreau (1867-1938)", Geografiska Annaler Series B, 99(3), 2017, pp. 238-255 http://www.tandfonline.com/doi/full/10.1080/04353684.2017.1353887 
to assume a male-like identity, presenting herself as more politically conservative and authoritarian than her husband, representing a step backward from Henri Coudreau's attempts to know indigenous people through empathy and common living (Coudreau, 1887 and 1893).

This raises the problem of Octavie's connection to the socialist and anarchist circuits that her husband frequented, especially that of Reclus, who used Henri as the informer for his New Universal Geography for Amazonia and Guiana, a work in which the anarchist geographer expressed ideas rather far from those of Octavie, such as his praise for the communities of ancient slaves who represented to him a history of resistance, forming communities whose members 'live in pace, without rival ambitions disputing for power, equal in wealth, the black people of the bush are equal in right' (Reclus 1894, 52) and blaming French rule in South America, by arguing that, 'of all the overseas possessions that France has arrogated to itself, none prospers less than its part of the Guianas; one cannot relate this history without shame' (Reclus 1894, 72). After 1901, Octavie's maps were no longer engraved in Brussels, her books no longer advertised in the Humanité Nouvelle and we do not know if Reclus had further contact with her after his 1903 letters to Schiffer. It is possible to hypothesise a progressive estrangement of Octavie from the political circuits frequented by her husband or even that Reclus's entourage was unhappy with some statements of her last books, judged too racist, leading to the end of the collaboration. According to Mouchet, after her return in France in 1906 where she lived in the Coudreau's family house until her death in 1938, Octavie Renard no longer travelled, wrote, or dealt with politics, and this biographer also evoked possible mental health issues. Regardless, this case confirms that the tropics implied, for most of the Europeans (men and women) who visited them, what Felix Driver (2004) called a 'disturbance', after which their views no longer remained the same, though with diverse outcomes. In her last book, Octavie Renard argued that: 'fourteen years spent in the Great Wood rendered me a savage, and savage I must remain to be happy' (Renard-Coudreau 1906, 3-4).

\section{Reference list}

2017, "Imperial ambivalences. Histories of lady travellers and the French explorer Octavie Renard-Coudreau (1867-1938)", Geografiska Annaler Series B, 99(3), 2017, pp. 238-255 http://www.tandfonline.com/doi/full/10.1080/04353684.2017.1353887 
Baigent, E. 2004. "The geography of biography, the biography of geography: rewriting the Dictionary of National Biography." Journal of Historical Geography 30(3): 531-551. doi:10.1016/s0305-7488(03)00044-6

Bell, M and C. McEwan. 1996. "The admission of women fellows to the Royal Geographical Society, 1892-1914: the controversy and the outcome.” The Geographical Journal 162(3): 295312. doi:10.2307/3059652

Benoit, S. 2000. Henri Anatole Coudreau (1859-1899), dernier explorateur français en Amazonie [Henri Anatole Coudreau (1859-1899), the last French explorer in Amazonia]. Paris, L'Harmattan.

Blunt, A. 1994a. Travel, Gender and Imperialism, Mary Kingsley and West Africa. New York and London: Guilford Press.

Blunt, A. 1994b. "Mapping authorship and authority: Mary Kingsley's landscape descriptions." In Writing Women and Space, Colonial and Post-Colonial Geographies edited by A. Blunt and G. Rose, 51- 72. New York and London: Guilford Press.

Blunt, A. and Rose, G. 1994. "Introduction, women's colonial and postcolonial geographies." In Writing Women and Space, Colonial and Post-Colonial Geographies edited by A. Blunt and G. Rose, G., 1-25. New York and London: Guilford press.

Blunt, A. and C. McEwan. 2002. Postcolonial Geographies. New York: Continuum.

Buck-Morss, S. 2009. Hegel, Haiti and Universal History. Pittsburgh: University of Pittsburgh Press.

Burnett G. 2000. Masters of all they Surveyed, Exploration, Geography and a British El Dorado. Chicago: University of Chicago Press.

Coquery-Vidrovitch, C. 2003. "Le postulat de la supériorité blanche et de l'infériorité noire." In Le livre noir du colonialisme [The Black Book of Colonialism] edited by M. FERRO, 646-691. Paris:Laffont.

Coudreau, H. 1886 La France équinoxiale, vol. I. [Equinoctial France, vol. I]. Paris : Challemel.

Coudreau, H. 1887. La France équinoxiale, vol. II. [Equinoctial France, vol. II]. Paris: Challemel.

Coudreau, H. 1893. Chez nos Indiens [With Our Indians]. Paris : Hachette.

2017, "Imperial ambivalences. Histories of lady travellers and the French explorer Octavie Renard-Coudreau (1867-1938)", Geografiska Annaler Series B, 99(3), 2017, pp. 238-255 http://www.tandfonline.com/doi/full/10.1080/04353684.2017.1353887 
Coudreau, H. 1897a. Voyage au Tapajos, 28 juillet 1895- 7 janvier 1896 [Travel to the Tapajos River, 28 July 1895 - 7 January 1996]. Paris : Lahure.

Coudreau, H. 1897b. Voyage au Xingu, 30 mai 1896, 26 octobre 1896 [Travel to the Xingu River, 30 May 1896 - 26 October 1896]. Paris: Lahure.

Coudreau, H. 1897c. Voyage au Tocantins-Araguaya, 31 décembre 1896- 23 mai 1897 [Travel to the Tocantins-Araguaya Rivers, 31 December 1896 - 23 May 1897]. Paris : Lahure.

Coudreau, H. 1898a. Voyage à Itaboca et à l'Itacayuna, $1^{\text {er }}$ juillet - 11 octobre 1897 [Travel to the Itaboca and Itacayuna Rivers, 1 July - 11 October 1897]. Paris : Lahure.

Coudreau, H. 1898b. Voyage entre Tocantins et Xingú, 3 avil- -3 novembre 1898 [Travel between the Tocantins and Xingu Rivers, 3 April - 3 November 1898]. Paris : Lahure.

Coudreau, H. 1899. Voyage au Yamunda, 21 janvier 1899 - 27 juin 1899 [Travel to the Yamunda River, 21 January 1899 - 27 June 1899]. Paris: Lahure.

Domosh, M. 1991. "Beyond the frontiers of geographical knowledge." Transactions of the Institute of British Geographers 16 (4): 488-490. doi:10.2307/623033

Domosh, M. and K. Morin. 2003. "Travels with feminist historical geography." Gender, Place \& Culture: A Journal of Feminist Geography 10 (3): 257-264. doi:10.1080/0966369032000114028

Domosh, M. and J. Seager. 2001. Putting Women in Place: Feminist Geographers Make Sense of the World. New York and London: Guilford Press.

Driver, F. 2001. Geography Militant: Cultures of Exploration and Empire. Oxford: Blackwell.

Driver, F. 2004. "Imagining the tropics: views and visions of the tropical world." Singapore Journal of Tropical Geography 25(1): 1-17. doi:10.1111/j.0129-7619.2004.00167.x

Evans, S.L., Keighren, I.M. and A. Maddrell. 2013. "Coming of age? Reflections on the centenary of women's admission to the Royal Geographical Society." The Geographical Journal, 179 (4): 373-376. doi:10.1111/geoj.12051

Ferretti, F. 2013. "They have the right to throw us out: Élisée Reclus' Universal Geography." Antipode, a Radical Journal of Geography 45(5): 1337-1355. 10.1111/anti.12006

Ferretti, F. 2015. "A new map of the Franco-Brazilian border dispute (1900).” Imago Mundi 67 (2): 229-242.

2017, "Imperial ambivalences. Histories of lady travellers and the French explorer Octavie Renard-Coudreau (1867-1938)", Geografiska Annaler Series B, 99(3), 2017, pp. 238-255 http://www.tandfonline.com/doi/full/10.1080/04353684.2017.1353887 
Ferretti, F. 2016a. "The murderous civilization: anarchist geographies, ethnography and cultural differences in the works of Elie Reclus." Cultural Geographies [early view], http://cgj.sagepub.com/content/early/2016/08/09/1474474016662293.full doi:10.1177/1474474016662293

Ferretti, F. 2016a. "Anarchist geographers and feminism in late 19th century France: the contributions of Elisée and Elie Reclus." Historical Geography [special number on Feminist Historical Geographies, edited by M. Domosh, K. Morin, T. Rothenberg] forthcoming.

Ferretti, F. 2017. "Tropicality, the unruly Atlantic and social utopias: the French explorer Henri Coudreau (1859-1899)." Singapore Journal of Tropical Geography, 38(1) [forthcoming].

Georlette, F. 1903. "Exploration de l'Amazonie.” Bulletin de la Société Géographique d'Anvers, 27(3): 325-328.

Godlewska, A. 1999. Geography Unbound: French Geographic Science from Cassini to Humboldt. Chicago: The University of Chicago Press.

Guelke, J.K. and K. Morin. 2001. "Gender, nature, empire: women naturalists in nineteenth century British travel literature." Transactions of the Institute of British Geographers, 26(3): 30626.

Keighren, I.M., Withers, C.W.J. and B. Bell. 2015. Travels into Print: Exploration, Writing, and Publishing with John Murray, 1773-1859. Chicago: Chicago University Press.

Kennedy, D. 2014. "Introduction: reinterpreting exploration". In Kennedy, D. ed., Reinterpreting Exploration, the West in the World, 1-20. Oxford, Oxford University Press.

Livingstone, D.N. 2003. Putting Science in its Place, Geographies of Scientific Knowledge. Chicago: Chicago University Press.

Livingstone, D.N. 2010. "Cultural politics and the racial cartographics of human origins." Transactions of the Institute of British Geographers, 35(2):204-221.

Lykknes, A., Opitz, D.L., Van Tiggelen, B. (eds.) 2012. For Better or For Worse? Collaborative Couples in the Sciences. Basel: Springer.

Maddrell, A. 1997. "Marion Newbigin and the scientific discourse." Scottish Geographical Magazine 113(1): 33-41. doi:10.1080/00369229718736988

2017, "Imperial ambivalences. Histories of lady travellers and the French explorer Octavie Renard-Coudreau (1867-1938)", Geografiska Annaler Series B, 99(3), 2017, pp. 238-255 http://www.tandfonline.com/doi/full/10.1080/04353684.2017.1353887 
Maddrell, A. 2009. Complex Locations: Women's Geographical Work in the UK 1850-1970. Oxford: Wiley-Blackwell.

Maldonado-Torres, N. 2016. "Colonialism, neocolonial, internal colonialism, the postcolonial, coloniality, and decoloniality." In Critical terms in Caribbean and Latin American Thought: Historical and Institutional and Trajectories edited by Y. Martínez San Miguel, B. SifuentesJauregui, and M. Belausteguigoitia, 67-78. New York Palgrave: Press.

Martins, L. 2007. "Illusions of power: vision, technology and the geographical exploration of the Amazon, 1924-1925." Journal of Latin American Cultural Studies 16(3): 285-307. doi:10.1080/13569320701682518

McEwan, C. 1994. "Encounter with West African women: textual representations of difference by white women abroad." In Writing Women and Space, Colonial and Post-Colonial Geographies edited by A. Blunt, A. and G. Rose, 73-100. New York and London: Guilford Press. Mignolo, W. 2000. Local Histories/Global Designs: Coloniality, Subaltern Knowledges, and Border Thinking. Princeton: Princeton University Press.

Mills, S. 1994. "Knowledge, gender and empire." In Writing Women and Space, Colonial and Post-Colonial Geographies edited by A. Blunt, A. and G. Rose, 29-50. New York and London: Guilford press.

Monk, J., Fortuijn, J.D. and C. Raleigh. 2004. "The representation of women in academic geography: contexts, climate and curricula." Journal of Geography in Higher Education 28(1): 83- 90. doi:10.1080/0309826042000198657

Morier-Genoud, E. and Cahen M. (eds). 2012. Imperial Migrations. Colonial Communities and Diaspora in the Portuguese World. London: Palgrave.

Morin K., and Berg L. 1999. "Emplacing current trends in feminist historical geography." Gender, Place \& Culture: A Journal of Feminist Geography, 6 (4): 311-330. doi:10.1080/09663699924917

Morrissey, J. 2004. "Geography militant: resistance and the essentialisation of identity in colonial Ireland.” Irish Geography, 37 (2): 166-176. doi:10.1080/00750770409555840

Mouchet M. 1973. L'Explorateur Coudreau ou la Philosophie des voyages. Melun: Imprimerie Tschumi-Taupin.

2017, "Imperial ambivalences. Histories of lady travellers and the French explorer Octavie Renard-Coudreau (1867-1938)", Geografiska Annaler Series B, 99(3), 2017, pp. 238-255 http://www.tandfonline.com/doi/full/10.1080/04353684.2017.1353887 
Murari, L. 2007. Brasil, ficção geográfica [Brazil, Geographical Fiction]. São Paulo: Annablume.

Nash, C. 2015. Genetic Geographies, The Trouble with Ancestry. Minneapolis: University of Minnesota Press.

Naylor, S. 2005. "Historical geography: knowledge, in place and on the move." Progress in Human Geography 29(5): 626-634. doi:10.1191/0309132505ph573pr

Naylor, S. and Ryan, J.R. 2010. Exploration and the twentieth century. In Naylor, S. and Ryan J.R. (eds). New Spaces of Exploration. Geographies of Discovery in the Twentieth Century. London: Tauris.

Pereira Carris Cardoso, L. 2015. "A vulgarização da região amazônica: Os Franceses na Amazônia de Henri Coudreau." Terra Brasilis http://terrabrasilis.revues.org/1287

Pereira Carris Cardoso, L. 2016. Intelectuais, militares, instituições na configuração das fronteiras brasileiras. 1883-1903 [Intellectuals, Militaries and Institutions in the Configuration of Brazilian Frontiers, 1883-1903]. São Paulo: Alameda.

Porto-Gonçalves, C.W. and Araújo Quental, P. 2012. "Colonialidade do poder e os desafios da integração regional na América Latina”. Polis, 31 http://polis.revues.org/3749

Pycior, H.M., Slack, N.G., Abir-Am, P.G. (eds.) 1996. Creative Couples in the Sciences. New Brunswick: Rutgers University Press.

Reclus, E. 1894. Nouvelle Géographie Universelle, vol. XIX [New Universal Geography, Vol. $X I X]$ Paris : Hachette.

Renard-Coudreau, O. 1900. Voyage au Trombetas, 7 août 1899 - 25 novembre 1899 [Travel to the Trombetas River, 7 August - 25 November 1899]. Paris : Lahure.

Renard-Coudreau, O. 1901. Voyage au Cuminá, 20 avril 1900 - 7 septembre 1900 [Travel to the Cuminá River, 20 April 1900 - 7 September 1900]. Paris : Lahure.

Renard-Coudreau, O. 1903a. Voyage au Rio Curua, 20 novembre 1900 - 7 mars 1901 [Travel to the Curua River, 20 November 1900 - 7 March 1901]. Paris : Lahure.

Renard-Coudreau, O. 1903b. Voyage à la Mapuerá, 21 avril 1901 - 24 décembre 1901 [Travel to the Mapuerá River, 21 April 1901 - 24 December 1901]. Paris : Lahure.

2017, "Imperial ambivalences. Histories of lady travellers and the French explorer Octavie Renard-Coudreau (1867-1938)", Geografiska Annaler Series B, 99(3), 2017, pp. 238-255 http://www.tandfonline.com/doi/full/10.1080/04353684.2017.1353887 
Renard-Coudreau, O. 1903c. Voyage au Maycurú, 5 juin 1902 - 12 janvier 1903 [Travel to the Maycurú River, 5 June 1902 - 12 January 1903]. Paris : Lahure.

Renard-Coudreau, O. 1906. Voyage au Canumã: 21 août 1905-16 février 1906 [Travel to the Canuma River, 21 August 1905 - 16 February 1906]. Paris : Lahure.

Reynaud-Paligot, C. 2006. La république raciale: paradigme racial et idéologie républicaine, 1860-1930 [The Racial Republic: Racial Paradigm and Republican Ideology] Paris : PUF.

Rose, G., and Ogborn, M. 1988. "Feminism and historical geography". Journal of Historical Geography 14 (4): 405-409. doi: 10.1016/s0305-7488(88)80040-9

Rossiter, M.W. 1993. "The Matthew Matilda effect in science”. Social Studies of Science, 23 (2): 325-341.

Staszak, J.F. 2009. "Other/Otherness." In International Encyclopaedia of Human Geography, edited by R. Kitchin and N. Thrift. Oxford: Elsevier.

Sidaway, J., Woon, C.Y. and J. Jacobs. 2014. "Planetary Postcolonialism.” Singapore Journal of Tropical Geography, 35(1): 4-21. doi:10.1111/sjtg.12049

Souza Filho, D. 2008. Os retratos dos Coudreau: Indios, civilização e miscigenação através das lentes de um casal de visionarios que percorreu a Amazonia em busca do "Bom Selvagem" (PhD Dissertation) University of Belem.

Stepan, N.L. 2000. “Tropical Modernism: Designing the Tropical Landscape”. Singapore Journal of Tropical Geography, 21(1): 76-91

Stoddart, D.R. 1991. "Do we need a feminist historiography of geography. And if we do, what should it be?" Transactions of the Institute of British Geographers 16(4): 484-7. doi: $10.2307 / 623032$

Trimer, N.F. 2009. Ciência, história e arte: obras raras e especiais do Instituto de Biociências da Universidade de São Paulo. São Paulo: EDUSP/FAPESP.

Zimmermann, M. 1900. “Nécrologie.” Annales de Géographie, 43(9), 86.

2017, "Imperial ambivalences. Histories of lady travellers and the French explorer Octavie Renard-Coudreau (1867-1938)", Geografiska Annaler Series B, 99(3), 2017, pp. 238-255 http://www.tandfonline.com/doi/full/10.1080/04353684.2017.1353887 